\title{
Oral rabies vaccination of foxes with one or two delayed distributions of SAG2 baits during the spring
}

\author{
Virginie BRUYÈRE ${ }^{\mathrm{a}}$, Philippe VUILLAUME ${ }^{\mathrm{b}}$, \\ Florence CLIQUET ${ }^{\mathrm{a}}$, Michel AUBERT ${ }^{\mathrm{a} *}$ \\ a AFSSA Nancy, Laboratoire d'études sur la rage et la pathologie des animaux sauvages, \\ B.P. 9, 54220 Malzéville, France \\ ${ }^{\text {b }}$ Entente interdépartementale de lutte contre la rage, B.P. 43, 54220 Malzéville, France
}

(Received 27 July 1999; accepted 28 January 2000)

\begin{abstract}
During the spring of 1997, various protocols of rabies vaccine bait (SAG2) distribution for foxes were compared: in the first test zone, a first distribution was organised at the end of April, followed by a second distribution two weeks later; in the second test zone, there was a first distribution at the same period as for the previous zone, followed by a second distribution four weeks later, at the end of May. In two control zones, a classical single bait distribution was organised during the same periods as for the second distribution in the respective test zones. No statistical differences were observed for adult foxes or fox cubs sampled in the test and control zones neither for baits uptake nor for seroconversion rate. However, seroconversion rates observed in fox cubs population were significantly higher $(P<0.01)$ in areas vaccinated at the end of May (43 and $56 \%)$ compared with those vaccinated at mid-May (24 and $20 \%)$. The vaccinal efficacy of baits was also significantly $(P<0.05)$ increased for the fox cubs in the areas vaccinated at the end of May (46 and 57\%) compared with those vaccinated at mid-May (24 and $25 \%$ ). This increase in immunological response by fox cubs when vaccinating in late spring must be related to their development. In the early spring, fox cubs are generally too young to have access to baits or to be vaccinated when eating them. For most of these fox cubs, a second distribution will not constitute a booster. Therefore, in order to increase the efficient access of fox cubs to vaccine baits, Spring distribution of baits should preferably be organised during May or June rather than in April.
\end{abstract}

rabies / oral vaccination / fox cub / delayed double bait distribution

Resumé - Vaccination orale des renards avec une ou deux distributions successives d'appâts SAG2 au printemps. Lors de la campagne de vaccination orale des renards contre la rage en France au printemps 1997, différents protocoles de distribution des appâts vaccinaux (SAG2) ont été comparés : dans une première zone test, une distribution fin avril suivie d'une seconde deux semaines plus tard à la mi-mai et dans une deuxième zone test, une distribution fin avril suivie d'une seconde,

* Correspondence and reprints

Tel.: (33) 3832989 50; fax: (33) 3832989 59; e-mail : maubert@ fitech.fr 
quatre semaines plus tard, fin mai. Dans les zones témoins, une distribution classique et unique a été réalisée à la mi-mai ou fin mai. Aucune différence significative n'a été notée entre les taux de prise d'appâts, ni entre les taux de séroconversion chez les renards jeunes ou adultes prélevés dans les zones tests et témoins. Cependant, les taux de séroconversion obtenus chez les renardeaux dans toutes les zones vaccinées fin mai ont été significativement $(P<0.01)$ plus élevés que dans les zones vaccinées à la mi-mai (43 et $56 \%$ contre 24 et $20 \%$ respectivement). Chez les renardeaux également, l'efficacité vaccinale des appâts a été significativement plus élevée $(P<0.05)$ dans les zones vaccinées fin mai (46 et $57 \%$ ) que dans les zones vaccinées à la mi-mai (24 et $25 \%$ ). L'amélioration de la réponse immunitaire chez les renardeaux lorsque la date de la campagne est retardée doit être corrélée à leur développement. Au début du printemps, les renardeaux sont trop jeunes pour avoir accès aux appâts ou pour se vacciner quand ils les consomment. Dans ce cas une seconde distribution d'appâts ne peut provoquer chez eux un effet rappel. Une campagne de printemps menée tardivement (en mai ou juin) plutôt qu'en avril permet aux renardeaux d'accéder en nombre plus important et de façon plus efficace aux appâts vaccinaux.

rage / vaccination orale / renardeau / double distribution d'appâts différée

\section{INTRODUCTION}

The first fox rabies vaccination field trials using vaccine baits were initiated in Switzerland in 1978 [22]. Following other European countries, the first French oral vaccination campaigns were organised in 1986 [1], review in [5]. Since then, two campaigns have been organised annually during the spring and autumn.

Following spring campaigns, $70 \%$ of adult foxes but only 20 to $30 \%$ of fox cubs consumed vaccine baits as revealed by tetracycline marks in their teeth (a biological marker incorporated in the bait envelope) [15]. In parallel, the proportion of individuals with rabies antibodies among those marked with tetracycline is lower in fox cubs than in adults [23]. In fact, during the spring, two thirds of the fox population are cubs, therefore the key of a successful oral vaccination program is to give the fox cubs access to baits and to immunise them [8, 15].

Several methods have been tested for increasing vaccination coverage of fox cubs:

- to distribute baits at the entrance of fox dens during June [8, 23, 24],

- to distribute baits during the summer when cubs are starting to disperse [18] and as tested by Masson and Aubert in 1994 [16] to distribute baits twice during the spring at a two-week interval. By doing so, they hypothesised that fox cubs would have more of a chance to undertake several bait meals consisting of primovaccination and boosters. However, due to the effort required by the size of the area to vaccinate [3], the validity of this assumption was not assessed until the study described here which was undertaken in 1997. The objective was to compare the bait uptake and seroconversion rates in foxes sampled in areas vaccinated once or two times during the spring.

\section{MATERIALS AND METHODS}

\subsection{Study areas (Fig. 1)}

The study was carried out on the major part of the $23333 \mathrm{~km}^{2}$ vaccinated in France during spring 1997 . Tested areas covered $7496 \mathrm{~km}^{2}$ (A1: $2340 \mathrm{~km}^{2}$; A2: $5156 \mathrm{~km}^{2}$ ) and control areas $12492 \mathrm{~km}^{2}$ (B1: $3038 \mathrm{~km}^{2}$; B2: $2947 \mathrm{~km}^{2}$ ). They were limited by natural or artificial barriers: rivers, channels and high traffic roads. Two vaccination campaigns had been carried out similarly on these test and control areas previously during the spring and autumn of 1996. During the spring of 1997 , test areas were vaccinated two times: A1 on the end of April and mid-May; A2 on the end of April and end of May. Control areas were vacci- 


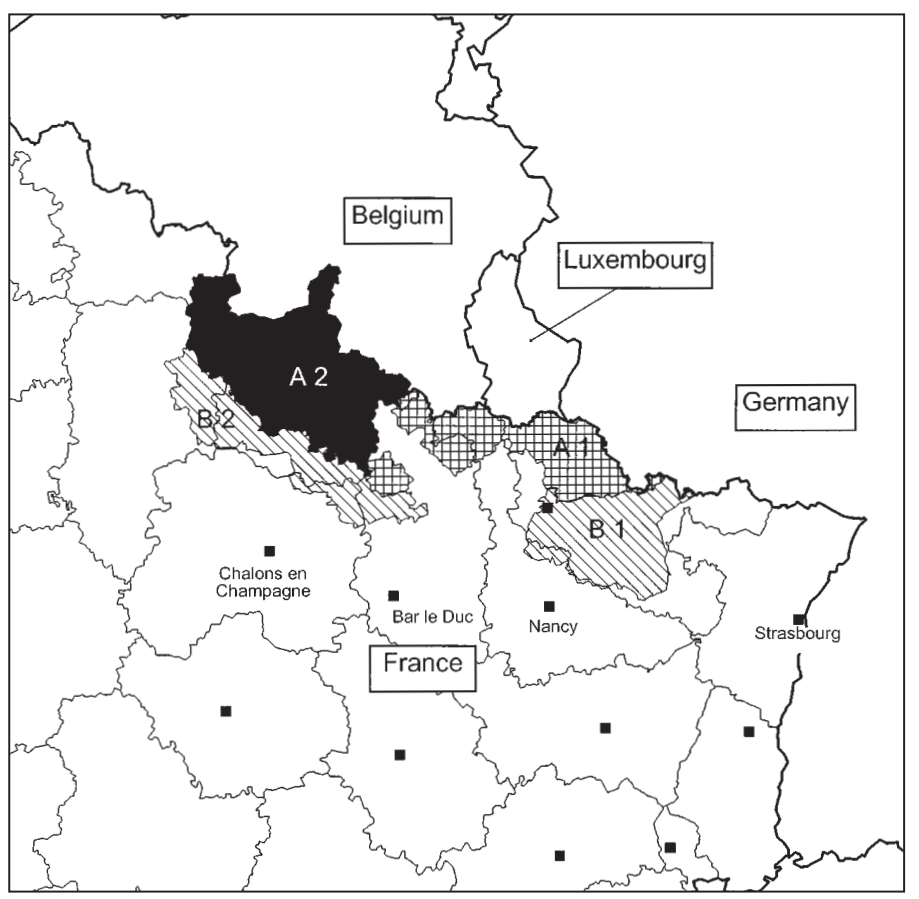

Figure 1. Location of the areas that were vaccinated in the spring 1997 with SAG2 baits.

Test areas: A1: two distributions of rabies vaccine baits (end of April and mid-May); A2: two distributions of rabies vaccine baits (end of April and end of May). Control areas: B1: a single distribution of rabies vaccine baits in midMay; B2: a single distribution of rabies vaccine baits in end of May.

nated only once on the same dates as for the second vaccination in tested areas. B1 during mid May (corresponding to A1), and B2 at the end of May (corresponding to A2).

\subsection{Vaccines}

Double and unique spring vaccinations in the test and control areas used the SAG2 (Rabigen ${ }^{\circledR}$ Virbac) vaccine bait, a highly attenuated double mutant of the already attenuated SAD Bern rabies strain [20]. The efficacy and innocuity of this vaccine was demonstrated in our experimental farm and in the fields [4, 17]. As usual, during the campaigns, all vaccine batches were carefully followed and 160 vaccine baits were sampled "from the helicopters" before, dur- ing and after dropping. They were all individually titrated. The lower titre was $10^{8.4}$ $\mathrm{TCID}_{50}$ per bait which is in compliance with French specifications for vaccination campaigns.

\subsection{Methods for bait distribution}

Baits were distributed from helicopters as previously described [18]. This procedure revealed to be more cost-effective and reliable than the use of pedestrian teams [5, $18,23]$. The flights were recorded using a GPS (Global Positioning System) for assessing the uniformity of bait distribution. Bait density per square $\mathrm{km}$ was 15 and 18 during April and May respectively. 


\subsection{Follow up of vaccination efficacy}

From 10 June until 15 September 1997, foxes were shot down during the night according to Roboly [19] in the test and control areas. All were blood sampled just immediately after death. Only the 200 blood samples and fox heads that reached the laboratory within less than 48 hours in good condition were used for this study. Among these samples 58, 29, 68 and 45 were from areas $\mathrm{A} 1, \mathrm{~B} 1, \mathrm{~A} 2$ and $\mathrm{B} 2$ respectively.

Tetracycline, a biological marker (150 mg per bait), was searched for in the lower jaw and inferior canine of foxes and detected by ultraviolet light examination of a section of the canine by inverse microscopy (model IMT 2-RFL, Olympus). Longitudinal sections of canines and lower jaws (thickness 500-700 $\mu \mathrm{m}$ ) were prepared with a diamond circular saw (model Buehler-isomet $\left.^{\text {nd }}\right)$. Tetracycline deposits appeared as pale yellow on a blue background [12]. According to Kappeler [13] and Masson [15] bait uptake must be studied in fox cubs (that is in foxes less than 12 months of age) and adult foxes separately; therefore, we differentiated both age categories on the basis of histological dental examination as described by Johnston and Watt [11].

Sera were titrated for rabies antibodies by an ELISA technique developed by Atanasiu and Perrin [2]. The ELISA test used sensitised plates of 96 wells in polystyrene purchased from Diagnostics Pasteur, France. The wells of the rabies glycoprotein sensitised plates were rinsed eight times with a washing buffer (consisting of $\mathrm{NaCl}, 0.9 \%$; Tween 20, 0.1\%) and shaken until dry. A $100 \mu \mathrm{l}$ quantity of the prediluted (1:100) sera to be examined, was added. Each serum was tested at a single dilution in duplicate. After a 1-hour incubation at $37{ }^{\circ} \mathrm{C}$, serum samples were removed and the plates washed 8 times. A $100 \mu 1$ sample of a prediluted (1:8000) Horse radish peroxidase (HRPO)-conjugated anticanine IgG (Biosys, Compiègne, France) was added to each well of the plates, and left for 1 hour at $37{ }^{\circ} \mathrm{C}$. After 8 additional washing steps, $100 \mu \mathrm{l}$ of peroxidase substrate (consisting of a mixture of 1 tablet of orthophenylenediamine per plate in citrate buffer $0.025 \mathrm{M}, 0.025 \%$ hydrogen peroxide) was added. The mixture was incubated in the dark for $30 \mathrm{~min}$ at room temperature. Absorbance values were measured at $492 \mathrm{~nm}$ against a blank (Titertek Multiskan spectrophotometer) after stopping the reaction by adding $50 \mu \mathrm{l}$ of $\mathrm{H}_{2} \mathrm{SO}_{4} 4 \mathrm{~N}$ to each well.

The positive reference serum was prepared by pooling fields fox positive sera. Eight serial dilutions (the first one being $1: 1400)$ of this positive control were included in parallel in each test. The negative control consisted of pooled sera from unvaccinated foxes tested as negatives by a neutralisation test on cells, then re-tested by ELISA. The negative control was tested in duplicate at the single 1:100 dilution. For each tested serum, a specific optical density (OD) was calculated by subtracting the negative control average OD from the sample average OD obtained for that test. Sera titres were expressed as equivalent units per $\mathrm{mL}\left(\right.$ E.U. $\left.\cdot \mathrm{mL}^{-1}\right)$ corresponding to international units [2] by using the values obtained by the reference serum.

\subsection{Statistical interpretation}

For each area, three parameters were evaluated separately for adult foxes and fox cubs: the bait uptake rate (that is the percentage of foxes marked with tetracycline, each tetracycline deposit representing one or several baits consumed within a short period of time), the seroconversion rate, and the vaccinal bait efficacy defined as the proportion of foxes with rabies antibodies among those marked with tetracycline.

The variation of these parameters according to the date and the number of vaccinations was compared using the Fisher test [25]. 


\section{RESULTS (Tab. I)}

\subsection{Adult foxes}

When comparing bait uptake, seroconversion rate and vaccinal bait efficacy between test and control areas (A1 vs. B1, and $\mathrm{A} 2$ vs. B2), no significant differences were observed. But when comparing areas vaccinated in mid-May (A1 and B1) vs. areas vaccinated during late May (A2 and B2), the uptake rate was significantly higher in the second case $(P=0.04)$. However, antibody rate and vaccinal bait efficacy were not statistically different (at the $P=0.05$ level) according to the date of vaccination in May.

\subsection{Fox cubs}

For fox cubs, when comparing test and control areas (A1 vs. B1, and A2 vs. B2), bait uptake antibody rate, and vaccinal bait efficacy were not statistically different. However, when comparing areas vaccinated during late May (A2 and B2) instead of MidMay (A1 and B1), the seroconversion rate was significantly higher $(P=0.008)$ with a non-significant increase in bait uptake $(P=$ 0.09 ). The vaccinal efficacy of baits was also significantly increased when vaccinating in late May $(P=0.03)$.

\section{DISCUSSION}

The bait uptake rate, seroconversion rate and vaccinal bait efficacy in adult and fox cubs are pertinent parameters for comparing the efficacy of vaccination campaigns. However because rabies has almost been eliminated in France since 1996, the possible range of variation in rabies incidence is too minute to be considered as a parameter allowing comparison between vaccination protocols.

When comparing test and control areas, no significant benefit for the immunisation of adult foxes has been obtained with an additional vaccination campaign. As a matter of fact, all parameters are already so high after a single spring vaccination that producing any significant increase with an additional treatment appears difficult. Another reason for this lack of apparent difference, is that vaccination campaigns conducted

Table I. Tetracycline marking, seroconversion rate, and bait efficacy in adult foxes and fox cubs in test and control zones.

\begin{tabular}{|c|c|c|c|c|c|c|c|c|}
\hline \multirow[t]{2}{*}{ Areas } & \multirow[t]{2}{*}{ Size $\left(\mathrm{km}^{2}\right)$} & \multirow{2}{*}{$\begin{array}{l}\text { Dates of } \\
\text { campaigns }\end{array}$} & \multicolumn{3}{|c|}{ Adult foxes } & \multicolumn{3}{|c|}{ Fox cubs } \\
\hline & & & Tetracycline & $\begin{array}{l}\text { Rabies } \\
\mathrm{Ab}\end{array}$ & $\begin{array}{c}\text { Bait } \\
\text { efficacy }\end{array}$ & Tetracycline & $\begin{array}{c}\text { Rabies } \\
\mathrm{Ab}\end{array}$ & $\begin{array}{l}\text { Bait } \\
\text { efficacy }\end{array}$ \\
\hline A1 test & 2340 & $\begin{array}{l}\text { 21-28 April } \\
\text { and 12-16 May }\end{array}$ & $33 / 37(89)^{\mathrm{a}}$ & 29/37 (78) & $28 / 33(85)$ & 17/21 (81) & $5 / 21(24)$ & 4/17 (24) \\
\hline B1 control & 3038 & 12-16 May & 12/14 (86) & $11 / 14(79)$ & $10 / 12(83)$ & $12 / 15(80)$ & $3 / 15(20)$ & $3 / 12(25)$ \\
\hline A2 test & 5156 & $\begin{array}{l}\text { 21-28 April and } \\
26 \text { May-2 June }\end{array}$ & $40 / 40(100)$ & $30 / 40(75)$ & $30 / 40(75)$ & $26 / 28(93) 1$ & $12 / 28(43)$ & $12 / 26(46)$ \\
\hline B2 control & 2947 & 26 May-2 June & $19 / 20(95)$ & $13 / 20(65)$ & $12 / 19(63)$ & $23 / 25(92) 1$ & $14 / 25(56)$ & $13 / 23(57)$ \\
\hline
\end{tabular}

A1 and A2: test areas, with two distributions of antirabies baits. B1 and B2: control areas with a single distribution of antirabies baits. Tetracycline: tetracycline marking rate. Rabies Ab: seroconversion rate. Bait efficacy: vaccinal efficacy of baits. a: percentage. 
during the previous years may blur any slight variation in the efficacy of the last vaccination performed.

Because fox cubs were not born during previous vaccination campaigns, they only responded to the last spring vaccination. In western Europe, fox birth takes place from 15 March to 15 April [14,21] and weaning four to six weeks later, that is from midApril to late May. The possible transmission of tetracycline by the mother (during pregnancy or milk feeding), and any interference between antibody self-production and antibodies of maternal origin must be considered similar in test and control areas because these areas were equally vaccinated during the previous years. Interference between antibodies of maternal origin and active immunity after vaccination has been described in several carnivore species [6] and suggested in the fox by Brochier et al. [9] and Vuillaume et al. [24].

The results obtained in fox cubs following one or two distributions of baits during spring did not demonstrate any benefit of distributing baits two times at a few week interval. The proportion of fox cubs that had access to baits distributed during April was low, as revealed by the lack of any difference when distributing baits once during May or twice during April, then May. The active transport of entire baits by adult foxes to the den as proven by Vuillaume et al. [23, $24]$ and suggested by this study was not sufficient for compensating the limited access of cubs to the baits distributed by helicopters.

Vaccinating later during the spring did not entail a significantly greater bait uptake in fox cub population but a significant increase in seroconversion rate. Therefore, we conclude that the benefit of vaccinating later founds its origin not from an increase in bait uptake, but in a higher ability for fox cubs to use the baits more efficiently that is they do not consume the bait envelope without chewing the vaccine capsule. Additionally, when getting older, fox cubs develop a better ability to respond to vaccination (that is to produce rabies antibodies).

Brochier et al. [10] already hypothesised that when very young, cubs can chew the baits without puncturing the vaccine capsule. In this situation, fox cubs will be marked by tetracycline without being vaccinated. Several other explanations for discrepancy between high bait uptake by fox cubs and a poor vaccination coverage are: (a) vixens feed their weaning cubs by regurgitation [14]; regurgitated baits still contain tetracycline but the rabies antigen is destroyed by gastric acidity; (b) tetracycline can be transmitted by vaccinated mothers through the milk as demonstrated by Bugnon et al. (personal communication).

The relative inability of fox cubs to respond to vaccination has already been evoked by Vuillaume et al. [24] when vaccinating fox cubs by depositing baits at the entrances of fox dens. Difficulties in vaccinating young foxes have already been mentioned during early trials in our experimental farm with the attenuated rabies SAD strain [7]. However, with the VRG vaccine, young foxes (6 to 12 weeks old) born from non-vaccinated vixens could be efficiently immunised [9].

Considering that the key factor for the success of the vaccination campaign is to immunise fox cubs $[8,15]$ the most efficient and beneficial way of vaccinating during the spring consists in a single distribution of baits during late May.

\section{ACKNOWLEDGEMENTS}

The authors would like to thank A. Duranel, J.M. Demerson and F. Rosenthal for their technical support. The hunter's federations, the Office national de la chasse, the lieutenants de louveterie, the Directions des services vétérinaires and the laboratoires vétérinaires départementaux have given us special help. May they receive our gratitude and sincere recognition for their assistance in this project. 


\section{REFERENCES}

[1] Artois M., Chillaud T., Maillot E., Rigal P., Blancou J., Première campagne de vaccination antirabique du renard par voie orale menée en France. Contrôle d'efficacité chez le renard et d'innocuité chez les micromammifères, Ann. Méd. Vét. 131 (1987) 457-462.

[2] Atanasiu P., Perrin P., Microméthode immunoenzymatique de titrage des anticorps antirabiques: utilisation de la glycoprotéine rabique et de la protéine conjuguée à la péroxydase, Ann. Microbiol. (Institut Pasteur) 130 A (1979) 257-268.

[3] Aubert M., Epidémiologie et lutte contre la rage en France et en Europe, Bull. Acad. Natl. Méd. Paris 179 (1995) 1033-1054.

[4] Aubert M., Barrat J., Artois M., Schumacher C., Efficacy tests of SAG2 on target species, in: 4th WHO Consultation on oral Immunization of dogs against rabies, Geneva, Switzerland, 14-15 June 1993, WHO, 6 p.

[5] Aubert M., Masson E., Vuillaume P., Artois M., Barrat J., Les acquis de la prophylaxie contre la rage vulpine en France, Médecine et Maladies Infectieuses 23 (1993) 537-545.

[6] Bastian S., Gonon V., Vaccination du chiot en élevage, Recl. Méd. Vét. Ec. Alfort 172 (1996) 543-555.

[7] Blancou J., Schneider L.G., Wandeler A.I., Pastoret P.P., Vaccination du renard roux (Vulpes vulpes L.) contre la rage par voie orale. Bilan d'essais en station expérimentale, Rev. Ecol. Terre Vie. 40 (1985) 249-255.

[8] Breitenmoser U., Kaphegyi T., Kappeler A., Zanoni R., Significance of young foxes for the persistence of rabies in northern Switzerland, in: Schwyzer M., Ackermann M., Bertini G., Kocherhans R., McCullough K., Engels M., Wittek R. and Zanoni R. (Eds.), Immune biology of viral infections, Proc. 3rd Congress Europ. Soc. Vet. Virol. Interlaken, Switzerland, 4-7 September 1994, Fondation Mérieux, 1995, pp. 391-396.

[9] Brochier B.M., Languet B., Blancou J., Kieny M.P., Lecocq J.P., Costy F., Desmettre P., Pastoret P.P., Use of recombinant vaccinia - rabies virus for oral vaccination of fox cubs (Vulpes vulpes, $\mathrm{L}$ ) against rabies, Vet. Microbiol. 18 (1988) 103108.

[10] Brochier B., Costy F., De Coninck V., Hallet L., Bourhy H., Peharpre D., Mosselmans F., Beyer R., Lecomte L., Mullier P., Bauduin B., Pastoret P.P., Epidemiosurveillance de la rage en Belgique : recrudescence en 1994, Ann. Méd. Vét. 139 (1995) 263-273.

[11] Johnston D.H., Watt I.D., A rapid method for sectioning undecalcified carnivore teeth for aging, in: Chapman J.A., Pursley D. (Eds.), Proc. World- wide Furbearer Conference, 3-11 August 1980, Frostburg, Maryland, USA, pp. 407-422.

[12] Johnston D., Joachim D., Bachmann P., Kardong K., Stewart R., Dix L., Strickland M., Watt I., Aging furbearers using tooth structure and biomarkers, in: Nowak M., Baker J.A., Obbard M.E., Mallock B. (Eds.), Wild Furbearer Management and Conservation in North America. Principles and techniques, Ministry of Natural Resources, Ontario, 1987, pp. 219-242.

[13] Kappeler A., Die orale Immunisierung von Füchsen gegen Tollwut in der Schweiz, Thèse Doct. Sci. Nat., Univ. Berne, 1992, 146 p.

[14] Lloyd H.G., The red fox, Batsford B.T. (Ed.), London, 1980, 320 p.

[15] Masson E., Au-delà des chiffres... Suivi au laboratoire de l'efficacité des campagnes de vaccination orale des renards contre la rage, Bulletin épidémiologique mensuel de la rage animale en France 22 (1992) 1-5.

[16] Masson E., Aubert M., La vaccination orale des renards en 1994, Bulletin épidémiologique mensuel de la rage animale en France 24 (1994) 1-2.

[17] Masson E., Cliquet F., Aubert M., Barrat J., Aubert A., Artois M., Schumacher C.L., Safety study of the SAG2 rabies virus mutant in several non-target species with a view to its future use for the immunization of foxes in Europe, Vaccine 14 (1996) 1506-1510.

[18] Masson E., Bruyère-Masson V., Vuillaume Ph., Lemoyne S., Aubert M., Rabies oral vaccination of foxes during the summer with the VRG vaccine bait, Vet. Res. 30 (1999) 595-605.

[19] Roboly O., Contrôle sélectif des populations de renards par la méthode du tir de nuit, Recl. Méd. Vét. Ec. Alfort 155 (1979) 749-752.

[20] Schumacher C.L., Coulon P., Lafay F., Benejean J., Aubert M.F.A., Barrat J., Aubert A., Flamand A., SAG-2 oral rabies vaccine, Onderstepoort J. Vet. Res. 60 (1993) 459-462.

[21] Steck F., Wandeler A., The epidemiology of fox rabies in Europe, Epidemiol. Rev. 2 (1980) 71-95.

[22] Steck F., Wandeler A., Bichsel P., Capt S., Schneider L., Oral immunisation of foxes against rabies. A field study, Zentralbl Veterinaer Med B. 29 (1982) 372-396.

[23] Vuillaume P., Aubert M., Demerson J.M., Cliquet F., Barrat J., Breitenmoser U., Vaccination des renards contre la rage par dépôt d'appâts vaccinaux à l'entrée des terriers, Ann. Méd. Vét. 141 (1997) 55-62.

[24] Vuillaume P., Bruyère V., Aubert M., Comparison of the effectiveness of two protocols of antirabies bait distribution for foxes (Vulpes vulpes), Vet. Res. 29 (1998) 537-546.

[25] Zar J., Biostatistical analysis, Prentice-Hall inc. Englewood Cliffs, 1974. 